EKSISBANK Vol. 3 No. 1 Juni 2019

PENGARUH PERILAKU BERDAGANG TERHADAP KEUNTUNGAN PENJUALAN PADA PEDAGANG SEMBAKO DI PASAR TRADISIONAL PABURAN

(KAJIAN ETIKA BISNIS ISLAM)

Seliwati

Program Studi Ekonomi Syariah, STIE Syariah Indonesia Purwakara

email : seliwati33@gmail.com

\begin{abstract}
After the global economic crisis since 2008 many economic experts from various countries, especially in the West. Looking for alternative economic concepts that are more established to be implemented in order to get out of the global economic crisis. One alternative is the concept of Islamic economics or Islamic economics which is currently in great demand. With so many delinquency cases of business people or business, Islamic business ethics is very reference to business people so that they do not do too much delinquency in their many previous businesses. Lately, the rules of Islamic business ethics have quickly become the spotlight of various circles for his efforts to be more blessed, to develop according to the Shari'a without cheating in obtaining business profits, especially among medium-sized Islamic business ethics.

The research formulation in this thesis is: (1) is there an effect of trading behavior on the profit of the sale of the basic needs traders with the ethical study of Islamic business? (2) how big is the effect of trading behavior on sales profits on basic food merchants with the study of Islamic business ethics?

The purpose of this study was to determine the effect of merchant behavior on the profit of sales at the sembako merchants in the traditional Pabuaran market with the study of Islamic business ethics, and to find out the magnitude of the effect of trading behavior on the profit of sales at sembako merchants in the traditional Pabuaran market based on the study of Islamic business ethics.

The method used in this research is quantitative descriptive. Analysis of the data using normality, validity, reliability and linearity test, $t$ and Rsquare test processing the data using SPSS 22 for windows.

With the results obtained in this study the level of influence of variable $X$ on variable $Y$, from the results of Rsquare values the effect of independent variables (trading behavior) on the dependent variable (sales profit) of 48,9\%, while the remaining $51,1 \%$ is determined by the influence of factors others that were not explained in this study.

Based on the results of research and discussion of research it can be concluded that profits are influenced by the trading behavior of each trader. From the results of research, traders in Pabuaran Market have implemented Islamic business ethics with every trade transaction without selling defective or defective items that are not suitable for sale, do not reduce the scale or exaggerate but are adjusted to the needs of the buyer, fair in providing services that do not differentiate - the difference between buyers is still valid honest and friendly.
\end{abstract}

Keywords: Trade Behavior, Islamic Business Ethics, Sales Profit

\title{
ABSTRAK
}

Setelah krisis ekonomi global sejak tahun 2008 banyak diantara ahli ekonomi dari berbagai negara terutama di Barat. Mencari alternatif konsep ekonomi yang lebih mapan untuk diterapkan agar bisa keluar dari krisis ekonomi global. Salah satu alternatifnya adalah konsep ekonomi Islam atau ekonomi syariah yang pada saat ini banyak diminati. Dengan banyaknya kasus kenakalan para pelaku usaha atau bisnis munculah etika bisnis islam sangat menjadikan acuan untuk para pelaku bisnis agar tidak banyak melakukan kenakalan dalam bisnisnya yang banyak terjadi sebelumnya. Belakangan ini aturan etika bisnis isalam sontak menjadi sorotan dari berbagai kalangan untuk usahanya lebih berkah, berkembang dengan sesuai syariat tanpa kecurangan dalam memperoleh keuntungan usahanya, terutama dikalangan pedagang kecil menengah etika bisnis islam sudah diterapkan.

Rumusan penelitian dalam skripsi ini adalah : (1) adakah pengaruh perilaku berdagang terhadap keuntungan penjualan pada pedagang sembako dengan kajian etika bisnis islam? (2) seberapa besar pengaruh perilaku berdagang terhadap keuntungan penjualan pada pedagang sembako dengan kajian etika bisnis islam?. 


\section{EKSISBANK Vol. 3 No. 1 Juni 2019}

Tujuan dari penelitian ini adalah untuk mengetahui pengaruh perilaku pedagang terhadap keuntungan penjualan pada pedagang sembako di pasar tradisional pabuaran dengan kajian etika bisnis islam, dan untuk mengetahui besarnya pengaruh perilaku berdagang terhadap keuntungan penjualan pada pedagang sembako di pasar tradisional pabuaran berdasarkan kajian etika bisnis islam.

Adapun metode yang digunakan dalam penelitian ini adalah deskriptif kuantitatif. Analisis datanya dengan menggunakan uji normalitas, validitas, reabilitas serta uji linearitas, uji $t$ dan $\mathrm{R}_{\text {square }}$ pengolahan datanya menggunakan SPSS 22 for windows.

Dengan hasil yang diperoleh dalam penelitian ini besarnya tingkat pengaruh variabel $\mathrm{X}$ terhadap variabel $Y$, dari hasil nilai $R_{\text {square }}$ pengaruh variabel bebas (perilaku berdagang) terhadap variabel terikat (keuntungan penjualan) sebesar $48,9 \%$, Sedangkan sisanya $51,1 \%$ ditentukan oleh pengaruh faktor lain yang tidak dijelaskan dalam penelitian ini.

Berdasarkan hasil penelitian dan pembahasan penelitian dapat disimpulkan bahwa keuntungan memang dipengaruhi perilaku berdagang dari setiap pedagang itu sendiri. Dari hasil penelitian pedagang di Pasar Pabuaran sudah menerapkan etika bisnis islam dengan setiap transaksi dagangnya tanpa menjual barang rusak atau cacat yang sudah tidak layak jual, tidak mengurangi timbangan ataupun melebihkan tetapi disesuaikan dengan keperluan pembeli, adil dalam memberikan pelayanan tidak membeda bedakan pembeli tetap berlaku jujur dan ramah.

Kata kunci: Perilaku Berdagang, Etika Bisnis Islam, Keuntungan penjualan

\section{PENDAHULUAN}

\subsection{Latar Belakang}

Pada dasarnya manusia memiliki kebutuhan yang cukup banyak namun sebagai umat islam perlu diperhatikan etika berdagang dan cara bertransaksi atau jual beli melakukan perniagaan atas dasar suka sama suka dan atas dasar niat karena allah swt. Hal tersebut haruslah ada dalam sebua perniagaan dalam berdagang agar mendapatkan rizki dan kebutuhan yang halal dan ridha.

Demikian dengan meninjau kegiatan jual beli para pelaku dagang saya mengambil penelitian di pasar pabuaran karena berdasarkan riset pasar tersebut berada ditengah - tengah pemukiman masyarakat oleh karena itu dengan adat istiadat pedasaan dalam pasar perlu dilakukan penelitian untuk mengetahui potensi cara berdagang dan melakukan transaksi jual beli dengan konsumen sudah berjalan sesuai syariat atau bertentangan dengan syariat.

Dengan demikian sebuah keuntungan usahapun menjadi sorotan dan perlu diketahui dalam cara memperolehnya. Karena islam sudah mengajarkan cara memperoleh keuntungan tidak boleh berlebihan dan melanggar aturan hukum islam. Keuntungan juga tidak boleh didapat dengan cara yang curang, karena kecurangan bukan hanya menzalimi orang lain namun juga menghilangkan keberkahannya. Larangan mengambil keuntungan melalui penipuan juga sudah ditegaskan dalam hadis yang diriwayatkan Abu Hurairah ketika
Rosulullah SAW berpapasan dengan seorang penjual makanan atau bahan pokok dipasar. ${ }^{1}$

Rasulullah memberikan apresiasi yang lebih terhadap perdagangan dan rasulullah bersabda yang artinya " $90 \%$ rezeki Allah terdapat dalam perdagangan". Tetapi harus banyak di perhatikan dengan hal itu perlunya memperhatikan berdagang dengan nilai-nilai akhlak ataupun etika yang harus di perhatikan yang dijadikan landasan dalam bertransaksi. ${ }^{2}$ Kemudian munculah etika bisnis islam yang mengatur semua tatanan bisnis dan wirausaha disemua kalangan masyarakat.

Etika bisnis mengandung arti tersendiri yaitu Pengertian Etika, Akhlak yaitu 1stilah "etika" pertama kali diperkenalkan oleh Aristoteles dalam Ethica Nichomacheae, yang kemudian dianggap sebagai awal lahirnya etika. Secara etimologis, "etika" berasal dari bahasa Yunani "ethos" yang berarti "jiwa atau roh yang mendasari tindakan". 3

\subsection{Rumusan Masalah}

a. Adakah pengaruh perilaku berdagang terhadap keuntungan penjualan pada pedagang sembako di pasar tradisional pabuaran?

b. Seberapa besar pengaruh perilaku berdagang terhadap keuntungan penjualan

\footnotetext{
${ }^{1}$ Isnaini Harahap Dkk, Hadis-Hadis Ekonomi, (Jakarta: Kencana Prenadamedia Group. 2015), 99.

${ }^{2}$ H. Abdul Ghofur, Pengantar Ekonomi Syariah Konsep Dasar,Paradigma, Pengembangan Ekonomi Syariah, (Depok : Pt Rajagrafindo Persada, 2017), 108.

${ }^{3}$ Mukhtar Samad, Etika Bisnis Syariah Berbisnis Sesuai Dengan Moral Islam, (Yogyakarta : Sunrice Book, 2016),07.
} 
pada pedagang sembako di pasar tradisional pabuaran berdasarkan kajian etika bisnis islam?

\subsection{Tujuan Penelitian}

a. Untuk mengetahui pengaruh perilaku pedagang terhadap keuntungan penjualan pada pedagang sembako di pasar tradisional pabuaran dengan kajian etika bisnis islam.

b. Untuk mengetahui besarnya pengaruh perilaku berdagang terhadap keuntungan penjualan pada pedagang sembako di pasar tradisional pabuaran berdasarkan kajian etika bisnis islam.

\subsection{Penelitian Terdahulu}

Penelitian sebelumnya dilakukan Diah Sulistiyani, 2015 dengan judul penelitian "Pengaruh Pengetahuan Etika Bisnis Islami Dan Religiusitas Terhadap Perilaku Pedagang Muslim" menggunakan metode kuantitatif. Hasil penelitiannya Dari hasil uji parsial menunjukkan bahwa terdapat pengaruh yang signifikan antara variabel pengetahuan etika bisnis islami (X) terhadap variabel perilaku pedagang muslim (Y). Perbedaan penelitian terdahulu dengan yang diteliti adalah terletak pada judul, tempat dan maksud tujuan penelitian tersebut, serta metode penelitian yang berbeda.

\section{KAJIAN PUSTAKA}

\section{A. Perilaku Berdagang}

Secara bahasa perilaku berarti tingkah atau tindakan, sedangkan menurut terminologi perilaku adalah kegiatan atau aktivitas organisme makhluk hidup yang hubungan, Perilaku manusia pada hakikatnya adalah aktivitas atau tindakan manusia itu sendiri. ${ }^{4}$

Menurut pandangan Frizt Heider perilaku timbul dengan adanya pemicu suatu tindakan yang akan muncul dari tindakan yang akan dilakukan atas pemikiran dirinya sendiri dengan yang dibutuhkannya dalam suatu tindakan sikap atau inisiatif pemikiran. $^{5}$

Beberapa pembentukan perilaku yang dibentuk yaitu ${ }^{6}$ :

\footnotetext{
${ }^{4}$ Isnaini Harahap Dkk, Hadis-Hadis Ekonomi, (Jakarta: Kencana Prenadamedia Group. 2015),154

${ }^{5}$ Herri Zan Pieter Dkk, Pengantar Psikopatologi Untuk Keperawatan,(Jakarta : Kencana Prenadamedia Group, 2011), 4.

${ }^{6}$ Herri Zan Pieter Dkk,5.
}

1) Pembentukan Perilaku dengan Conditioning (Kebiasaan).

2) Pembentukan Perilaku Melalui Pengertian (Insight).

3) Pembentukan Perilaku Melalui Penggunaan Model.

\section{B. Keuntungan Penjualan}

Menurut Qal'ahjay, profit (keuntungan) adalah tambahan dana yang diperoleh sebagai kelebihan dari beban biaya produksi atau modal. Dalam an-nasyaburi menjelaskan bahwa untung adalah pertambahan dari modal pokok setelah ada unsur usaha perdagangn. ${ }^{7}$

Profit dalam bahasa arab disebut dengan alRibh yang berarti pertumbuhuhan dalam perdagangan. Profit merupakan pertambahan penghasilan dalam perdagangan. Kata ini disebut hanya satu kali dalam al-Quran yaitu ketika allah mengecam tindakan orang-orang munafik dalam surat al-Baqarah ayat $16^{8}$ :

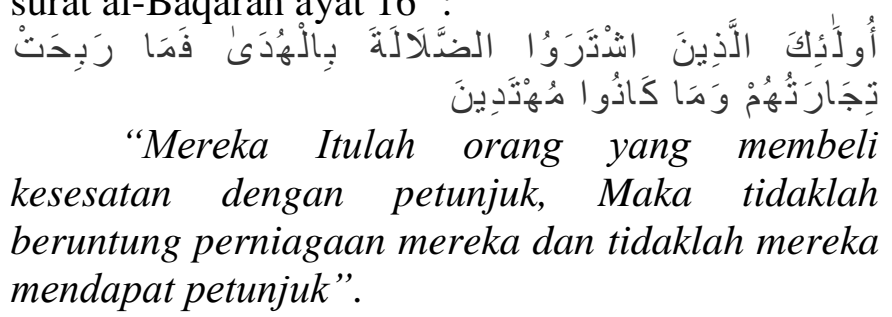

\section{Pedagang Sembako}

Pedagang Sembako adalah yang menjual sembilan bahan pokok kebutuhan untuk memenuhi konsumsi kehidupan masyarakat setiap harinya. ${ }^{9}$ Pedagang adalah orang yang yang melakukan perdagangan memperjual belikan barang yang tidak diproduksi sendiri untuk memperoleh suatu keuntungan. ${ }^{10}$

Perdagangan berdasarkan pengertian asal katanya dagang yaitu usaha yang berhubungan dengan menjual dan membeli barang untuk memperoleh keuntungan. Perdagangan dalam bahasa inggris adalah commerce, kemudian bahasa indonesianya menjadi komersil yang artinya usaha yang berhubungan dengan perdagangan jual beli barang atau jasa. ${ }^{11}$

\footnotetext{
${ }^{7}$ Isnaini Harahap Dkk, 92.

${ }^{8}$ Isnaini Harahap Dkk, 91.

${ }^{9}$ Buku Frofil Pasar Pabuaran Subang, Dinas Perindustrian Perdagangan Dan Pengelolaan Pasar Kabupaten Subang.

10 Dini Hertita, Setiap Pembisnis Harus Punya Buku Ini Rahasia Meningkatkan Income Dengan Pelayanan, ( Jakarta : Pt Elex Media Komputindo, 2018), 02.

${ }^{11} \mathrm{Hj}$. Apiaty Kamaluddin, Administrasi Bisnis, (Makasar: CV Sah Media, 2017), 47.
} 
Perdagangan dalam islam secara etimologi perdagangan yang intinya jual beli berarti saling menukar barang dengan uang dan lainnya yang menjadikan transaksi jual beli dalam islam disebut al-Bai muamalah. ${ }^{12}$

\section{Pasar Tradisional}

Pengertian pasar secara sederhana dapat diartikan sebagai tempat bertemunya para penjual dan pembeli untuk melakukan transaksi. Pengertian ini mengandung arti pasar memiliki tempat atau lokasi tertentu sehingga memungkinkan pembeli dan penjual bertemu, dalam arti lain didalam pasar terdapat penjual dan pembeli untuk melakukan transaksi jual beli produk baik barang maupun jasa saling tukar menukar melengkapi kebutuhan satu sama lain. Kebutuhan tersebut berupa kebutuhan sehari - hari atau kebutuhan jangka waktu panjang. ${ }^{13}$ Fungsi - fungsi pemasaran yang terdapat dalam pasar adalah sebgai berikut ${ }^{14}$ :
a) Fungsi pertukaran
b) Fungsi Distribusi Fisik
c) Fungsi perantara

\section{E. Etika Bisnis dalam Islam \\ 1. Pengertian Etika}

Istilah etika dalam bahasa Indonesia berasal dari bahasa Yunani, ethos, yang berarti kebiasaan atau watak Etika juga berasal dari bahasa Perancis, etiquette atau biasa diucapkan dalam bahasa Indonesia dengan kata etiket, yang artinya juga kebiasaan atau cara bergaul, berperilaku. Konsep etika lebih merupakan pola perilaku atau kebiasaan yang baik dan dapat diterima oleh lingkungan pergaulan seseorang atau suatu organisasi tertentu. ${ }^{15}$

Sedangkan menurut Achmad Charris Zubair menyatakan bahwa etika dan moral memiliki arti yang sama tetapi dalam pemakaian sehari - hari ada sedikit perbedaan. Moral atau moralitas dipakai untuk perbuatan yang sedang dinilai, sedangkan etika adalah aturan yang harus diikuti atau dipakai

${ }^{12}$ H. Abdul Ghofur, Pengantar Ekonomi Syariah Konsep Dasar,Paradigma, Pengembangan Ekonomi Syariah, (Depok : Pt Rajagrafindo Persada, 2017),107.

13 Arif Yusuf Hamali, Pemahaman Strategi Bisnis \& Kewirausahaan, ( Jakarta : Kencana Prenadamedia Group, 2016), 195.

14 Yaksan Hamzah Dkk, Etika Bisnis Islam, (Makasar :Kretakupa,2014), 120.

${ }^{15}$ Arif Yusuf Hamali, 270. dalam keadaan atau situasi tertentu dalam melakukan kegiatan sehari - hari. ${ }^{16}$

\section{Pengertian Bisnis}

Dalam ilmu ekonomi, bisnis adalah suatu organisasi yang menjual barang atau jasa kepada konsumen atau bisnis lainnya, untuk mendapatkan laba. Secara historis kata bisnis dari bahasa lnggris business, dari kata dasar busy yang berarti "sibuk" dalam konteks individu, komunitas ataupun masyarakat. Dalam artian, sibuk mengerjakan aktivitas dan pekerjaan yang mendatangkan keuntungan. ${ }^{17}$

Pengertian bisnis menurut Prof. L.R. dicksee adalah suatu bentuk aktivitas yang tujuan utamanya untuk memperoleh keuntungan bagi yang mengusahakan atau yang berkepentingan dalam terjadinya aktvitas tersebut.

Dalam bisnis sifatnya adalah berfokus pada aktivitas yang menitik beratkan pada hasil jangka panjang yang lebih besar. ${ }^{18}$

Sedangkan tujuan kebijakan bisnis terdapat beberapa hal yang tercantum dalam bagian tahapan berikut untuk kepentingan usaha perlu diperhatikan adalah $^{19}$ :

1) Melindungi usaha kecil dan menengah.

2) Melindungi lingkungan hidup sekitarya

3) Melindungi konsumen

Bisnis menurut islam segala aktivitas bisnis hendaklah dilakukan dengan penuh tanggungjawab. Tanggung jawab muncul karena manusia adalah makhluk mukalaf yaitu makhluk yang diberibeban hukum berbeda dengan makhluk lain seperti binatang dan tumbuh - tumbuhan. Karena taklif itulah manusia harus mempertanggung jawabkan segala aktivitasnya dan karena itu pula manusia disebut sebagai pimpinan oleh rasullullah. ${ }^{20}$

\section{Etika Bisnis}

Etika bisnis mengandung arti tersendiri adalah suatu kode etik perilaku pengusaha berdasarkan nilai-nilai moral dan norma yang

16 H. Idris, Hadis Ekonomi Ekonomi Dalam Perpektif Hadis Nabi Cetakan Ke - 3 Mei 2017, ( Jakarta : Kencana Prenadamedia Group, 2015 ), 323.

17 Sattar, Pengantar Bisnis, (Yogyakarta : Deepublish Grup Penerbitan Cv Budi Utama.2017), 03.

18 Dini Hertita, Setiap Pembisnis Harus Punya Buku Ini Rahasia Meningkatkan Income Dengan Pelayanan, ( Jakarta : Pt Elex Media Komputindo, 2018), 03

19 Sattar, Pengantar Bisnis, (Yogyakarta : Deepublish Grup Penerbitan Cv Budi Utama.2017), 6.

20 H. Idris, Hadis Ekonomi Ekonomi Dalam Perpektif Hadis Nabi Cetakan Ke - 3 Mei 2017, ( Jakarta : Kencana Prenadamedia Group, 2015 ), 353. 


\section{EKSISBANK Vol. 3 No. 1 Juni 2019}

dijadikan tuntunan dalam membuat keputusan dan memecahkan persoalan (Zimmerer). ${ }^{21}$

pengertian Etika Bisnis adalah suatu bagian yang tidak dapat dipisahkan dalam kegiatan bisnis yang dilakukan oleh para pelaku bisnis. Masalah etika dan ketaatan akan norma-norma agama dan hukum yang berlaku merupakan dasar yang kuat yang harus dimiliki oleh pelaku bisnis dan akan menentukan sikap atau tindakan yang perlu diambil dalam mengelolah bisnisnya.

Etika bisnis syariah berdasarkan kepada nilainilai dasar Islam yang terdiri dari aqidah, syariah dan akhlak, yang menjadi satu kesatuan utuh yang tidak boleh dipisahkan antara satu sama lainnya.

Nilai dasar syariah terdiri dari ibadah yang dibahas oleh fiqih ibadah, dan muamalah yang dibahas oleh fiqih muamalah diantaranya tentang ekonomi syariah, Sedangkan etika tergolong ke dalam nilai dasar akhlak moral Islam. ${ }^{22}$

\section{METODOLOGI PENELITIAN}

Metode penelitian yang saya gunakan adalah Deskriptif Kuantitatif yaitu metode dalam meneliti status sekelompok manusia, suatu objek, suatu set kondisi, suatu sistem pemikiran, ataupun suatu kelas peristiwa pada masa sekarang. Tujuan dari penelitian deskriptif ini adalah untuk membuat deskripsi, gambaran atau lukisan secara sistematis, faktual dan akurat mengenai fakta-fakta, sifat-sifat serta hubungan antar fenomena yang diselidiki. ${ }^{23}$ Penelitian deskriptif bisa mendeskripsikan suatu keadaan saja, tetapi bisa juga mendeskripsikan keadaan dalam tahapan - tahapan perkembangannya.

Menurut whitney pada tahun 1960 metode deskriptif adalah pencarian fakta dengan interprestasi yang tepat. Penelitian deskriptif mempelajari masalah - masalah dalam masyarakat, serta situasi - situasi tertentu termasuk tentang hubungan, kegiatan - kegiatan, sikap - sikap, pandangan - pandangan serta proses - proses yang sedang berlangsung dan pengaruh - pengaruh dari suatu fenomena yaitu permaslahan yang terjadi dan memicu suatu latar belakang penelitan terhadap suatu obyek yang dapat dilakukan penelitian

${ }^{21}$ Muhammad Anwar, Pengantar Kewirausahaan Teori Dan Aplikasi, (Jakarta : Kencana Prenadamedia Group, 2014), 90.

${ }^{22}$ Mukhtar Samad, Etika Bisnis Syariah Berbisnis Sesuai Dengan Moral Islam, (Yogyakarta : Sunrice Book, 2016), 3.

23 Moch Nazir, Metode Penelitian (Bogor:Ghalia Indonesia,2014), 43. sebelum dan sesuadah yang akan diteliti agar belum terdapat dijurnal apapunn. ${ }^{24}$

\section{A. Rancangan Penelitian}

Setelah data terkumpul tahapan selanjutnya adalah melakukan analisis terhadap data tersebut. Analisis data tentunya disesuaikan dengan tujuan dari riset yang dilakukan. Kajian dalam bidang penelitian sangat luas sehingga banyak sekali alat analisis yang dapat digunakan oleh para peneliti dalam mengolah datanya. Sedangkan aplikasi ilmu statistik dalam bisnis dapat dibagi dalam dua bagian namun pengolahan data yang digunakan dalam penelitian ini adalah statistik deskriptif. Statistik Deskriptif yaitu metode statistik yang berusaha menjelaskan atau menggambarkan berbagai karakteristik data, seperti berapa rataratanya, seberapa jauh data-data bervariasi dan sebagainya. ${ }^{25}$

\section{B. Populasi Dan Sampel Penelitian}

Dalam pengujian suatu data perlu diketahui populasi sampel terlebih dahulu maka pengertiannya dapat dipaparkan sebagai berikut :

\section{Populasi}

Populasi diartikan sebagai wilayah generalisasi yang terdiri atas: obyek atau subyek yang mempunyai kualitas dan karakteristik tertentu yang ditetapkan oleh peneliti untuk dipelajari dan kemudian ditarik kesimpulannya. ${ }^{26}$ Maka yang dapat dijadikan Pengambilan populasi: seluruh pedagang sembako sayuran yang jumlahnya 40 pedagang saja, dari keseluruhan pedagang jumlah Pasar Pabuaran berisi 124 brisi pakaian dan sebagainya.

Populasi dapat didefinisikan juga sebagai keseluruhan kelompok orang, kejadian atau hal minat yang ingin peneliti investigasi. Sementara Sugiyono mendefinisikan populasi sebagai wilayah generalisasi yang terdiri atas objek/subjek yang mempunyai kualitas dan karakteristik tertentu yang ditetapkan oleh peneliti untuk dipelajari dan kemudian ditarik kesimpulannya. Dengan demikian, dapat dinyatakan bahwa populasi adalah kelompok orang, kejadian, atau benda, yang

${ }^{24}$ Asep Saepul Hamdi Dkk, Metode Penelitian Kuantitatif Aplikasi Dalam Pendidikan, (Yogyakarta : Deepublish, 2014), 05 .

25 Muhammad, Metodelogi Penelitian Ekonomi Islam Pendekatan Kuantitatif, (Jakarta: Pt Rajagrafindo Persada, 2013), 207.

26 Sugiyono, Metode Penelitin Bisnis, (Jakarta : Alfabeta,2012), 389. 


\section{EKSISBANK Vol. 3 No. 1 Juni 2019}

memiliki karateristik tertentu dan dijadikan objek penelitian. ${ }^{27}$

\section{Sampel}

Sampel adalah sebagian dari populasi itu sendiri yang terdapat dalam suatu kelompok. ${ }^{28}$ Menurut Sheskin menjelaskan pengertian sampel yakni sekumpulan objek yang mewakili populasi. Sedangkan Lomax mengatakan bahwa sampel merupakan bagian dari populasi. ${ }^{29}$

Teori sampel ini mempelajari hubungan antara suatu populasi dengan sampel yang diambil dari populasi bersangkutan dan pengambilannya random sampling. ${ }^{30}$

Sedangkan untuk menentukan ukuran sampel dengan menggunankan teori isaac dan michael untuk tingkat kesalahan 5\% maka populasi yang jumlahnya 40, Karena tingkat kesalahan yang ingin diambil hanyalah sebesar 5\% maka peneliti mengambil 36 sampel. $^{31}$

\section{Teknik Pengumpulan Data}

\section{Teknik Pertanyaan/kuesioner (angket)}

Teknik ini sangat efektif dalam pendekatan survei dan lebih realibel jika pertanyaanpertanyaannya terarah dengan baik dan efektif. Teknik dapat berbentuk wawancara, baik wawancara terstruktur maupun tidak terstruktur, dan berbentuk pengisian kuesioner. Teknik ini merupakan bentuk alat pengumpulan data dalam bentuk pertanyaan-pertanyaan. Diharapkan dengan menyebarkan daftar pertanyaan kepada setiap responden, peneliti dapat menghimpun data yang relevan dengan tujuan penelitian dan memiliki tingkat reliabilitas serta validitas yang tinggi. ${ }^{32}$

Kuesioner memegang peranan penting dalam kesuksesan koleksi data pada setiap peneitian survey. Seberapa penting penyusunan suatu kuesioner seringkali diabaikan sehingga seperti setiap orang bisa membuat kuesioner sehingga sering terjadi kesalahan karna disebabkan salah penempatan pertanyaan atau tidak bisa

\footnotetext{
${ }^{27}$ Suryani dan Hendryadi., Metode Riset Kuantitatif Teori dan Aplikasi pada Penelitian Bidang Manajemen dan Ekonomi Islam, (Jakarta: Prenadamedia Group, 2015),190.

${ }^{28}$ Sugiyono, 389.

${ }^{29}$ H. Fajri Ismail, Statistika Untuk Penelitian Pendidikan Dan Ilmu - Ilmu Sosial Edisi Pertama, ( Jakarta : Kencana Prenada Media Group, 2018) 40

30 Muhammad, Metodelogi Penelitian Ekonomi Islam Pendekatan Kuantitatif, (Jakarta: Pt Rajagrafindo Persada, 2013), 166

31 Sugiyono, Statistika Untuk Penelitian, (Bandung : Alfabeta, 2017), $68-69$.

${ }^{32}$ Muhammad, 150.
}

memperhitungkan penyampaian yang kurang benar jadi harus dibuat sebenar mungkin demi data yang akurat. $^{33}$

\section{Teknik Wawancara}

Wawancara adalah teknik untuk mengumpulkan data yang akurat untuk keperluan proses pemecahan masalah tertentu, yang sesuai dengan data. Pencarian data dengan teknik ini dilakukan dengan cara tanya jawab secara lisan dan bertatap muka langsung.

Wawancara dilakukan antara seorang atau beberapa orang pewawancara dengan seorang atau beberapa orang yang diwawancarai. Wawancara juga merupakan kemampuan dan keterampilan mutlak yang harus dimiliki oleh setiap orang agar melengkapi informasi yang dibutuhkan sebagai pertimbangan langkah selanjutnya.

Jadi inti dari penjabaran teknik wawancara agar perolehan informasi lebih mendalam dan menguatkan keakuratan data yang akan diteliti dan dicari tahu untuk memenuhi data - data yang terdapat dalamsebuah kebutuhan informasi dan wawancara metode pertama yang digunakan dibanding alat lain dalam penelitian. ${ }^{34}$

Menurut Slamet menyebutkan bahwa wawancara adalah cara yang dipakai untuk memperoleh informasi melalui kegiatan interaksi sosial antara peneliti dengan yang diteliti. ${ }^{35}$ Dalam penelitian ini mengunakan wawancara tersetruktur yang mengandung pengertian secara umum wawan cara tersetruktur adalah menentukan terlebih dahulu data yang diperlukan. Pewawancara juga menyusun pertanyaan - pertanyaan dengan cara - cara tertentu agar memunculkan jawaban - jawaban yang berkorespondensi dengan kategori - kategori yang sudah ditentukan yang sudah ditentukan pada aspek teori. Wawancara ini sering digunakan dalam penelitian survey, walaupun dalam beberapa pertanyaan penelitian. ${ }^{36}$

\section{Teknik Dokumentasi}

Teknik dokumentasi digunakan untuk mengumpulkan data berupa data-data tertulis yang mengandung keterangan dan Penjelasan serta pemikiran tentang fenomena yang masih aktual dan sesuai dengan masalah penelitian. Teknik dokumentasi berproses dan berawal dari

${ }^{33}$ Eko Nugroho, Prinsip - Prinsip Menyusun Kuesoner, (Malang : UB Press,2018),20.

34 Fandi Rosi Sarwo Edi, Teori Wawancara Psikodignostik, ( Yogyakarta : Leutikaprio, 2016),1.

${ }^{35}$ Fandi Rosi Sarwo Edi, 2.

${ }^{36}$ Fandi Rosi Sarwo Edi, 19. 


\section{EKSISBANK Vol. 3 No. 1 Juni 2019}

menghimpun dokumen, memilih/ milih dokumen sesuai dengan tujuan penelitian, mencatat dan menerangkan menafsirkan hubungan-hubungan dengan fenomena lain. ${ }^{37}$

\section{Teknik Analisis Data}

\section{Uji Normalitas Data}

Uji ini digunakan untuk mengetahui kenormalan data sebelum menggunakan parametris atau nonparametris, maka kenormalan data harus diujikan terlebih dahulu. Untuk mempermudah pengujian normalitas data dan analisis selanjutnya maka pengujian ini perlu dilakukan, bila data tidak normal maka statistik parametris tidak dapat digunakan, untuk itu perlu digunakan statistik nonparametris. ${ }^{38}$ Uji normalitas bertujuan untuk menguji apakah dalam model regresi panel variabel - variabelnya berdistribusi normal atau tidak. Model regresi yang baik adalah memiliki distribusi data normal atau mendekati normal. ${ }^{39}$

\section{Validitas data}

Validitas adalah alat ukur yang digunakan untuk mendapatkan data (mengukur) itu valid. Valid berarti instrumen tersebut dapat digunakan untuk mengukur apa yang seharusnya diukur untuk keakuratan sebuah penelitian.

\section{Reliabilitas data}

Realibilitas sebenarnya mengacu pada konsistensi atau ketepercayaan hasil ukur, yang mengandung makna kecermatan. Untuk mengukur realibilita, alat ukur dalam penelitian ini menggunakan tekhnik varian dari Hoyt.

\section{Uji statistik / linieritas}

Linearitas adalah suatu uji yang digunakn untuk menentukan atau memutuskan apakah naik dan menurunnya variabel-variabel dependen dapat dilakukan melalui menaikkan dan menurunkan keadaan variabel independen ataupun sebaliknya. Dalam uji linearitas ini model regresi linear sederhana untuk mengetahui hubungan antara dua variabel yang salah satu variabel menjadi variabel dependent (tidak bebas) dan variabel lainnya independent (variabel bebas). Dalam analisis regresi linear, hasil akhir yang diperoleh adalah

37 Muhammad, Metodelogi Penelitian Ekonomi Islam Pendekatan Kuantitatif, (Jakarta: Pt Rajagrafindo Persada, 2013), 152.

38 Sugiyono, Statistika Untuk Penelitian, (Bandung : Alfabeta, 2017), 79.

${ }^{39}$ Ansofino Dkk, Buku Ajar Ekonometrika, (Yogyakarta : Deepublish, 2016 ), 22. fungsi regresi populasi yang didapat dari fungsi regresi sampel yang nantinya dapat digunakan untuk estimasi. ${ }^{40}$

\section{Uji t}

Merupakan pengujian non - parametrik yang digunakan untuk membandingkan dua kelompok yang berpasangan dengan cara melihat perbedaan dan besarnya perbedaan antara kedua kelompok yang dibandingkan. ${ }^{41}$

Uji t untuk dua sampel independen pada prinsipnya akan membandingkan rata-rata dari dua grup yang tidak berhubungan satu sama lain, dengan tujuan apakah kedua grup tersebut mempuyai rata-rata yang sama ataukah tidak secara signifikan. Sedangkan uji t paired berfungsi untuk menguji dua sampel yang berpasangan, apakah mempunyai rata-rata yang secara nyata berbeda ataukah tidak. ${ }^{42}$ Untuk menguji pengaruh variabel $\mathrm{X}$ terhadap $\mathrm{Y}$ rumusan hipotesisnya adalah ${ }^{43}$ :

Ho : $\beta_{1}=0$ ( Tidak ada pengaruh $\mathrm{X}$ terhadap $\mathrm{Y}$ )

$\mathrm{H}_{1}: \beta_{1}=0$ ( ada pengaruh $\mathrm{X}$ terhadap $\mathrm{Y}$ )

Menguji pengaruh positif dari variabel $\mathrm{X}$ terhdap variabel Y. Kriteria uji yang digunakan adalah : Tolak Ho jika $t>t_{a}$ Dimana $t_{a}$ didapat dari tabel distribusi t dengan derajat bebas n- 2 .

\section{6. $\mathbf{R}$ square}

Uji ini sering disebut $\mathrm{R}^{2}$ (Koefisien Determinasi) dimaknai sebagai sumbangan pengaruh yang diberikan variabel bebas (X) terhadap variabel terkait $(\mathrm{Y})$. Koefisien determinan $\mathrm{R}^{2}$ uji ini untuk mengukur seberapa banyak penyimpangan dalam memprediksi $\mathrm{Y}$ yang telah diberikan oleh kontribusi variabel X. Maka akan diketahui $\mathrm{x}$ memberikan kontrubusi atau tidak terhadap memprediksi Y. jika berkontribusi maka nilai $\mathrm{X}$ lebih kecil dari $\mathrm{Y}$ dan $\mathrm{X}$ mempunyai hubungan linear $\mathrm{Y}^{44}$

\section{Uji Hipotesis}

Teori hipotesis merupakan jawaban sementara terhadap rumusan masalah penelitian,

\footnotetext{
${ }^{40}$ Ansofino Dkk, 21

${ }^{41}$ Jonatan Sarwono \& Herlina Budiono, Statistik Terapan Aplikasi Untuk Riset Skripsi, Tesis Dan Disertasi, (Menggunakan Spss,Amos Dan Excel),(Jakarta : Pt Elex Media Komputindo, 2012), 24.

${ }^{42}$ Muhamad, Metodelogi Penelitian Ekonomi Islam Pendekatan Kuantitatif (Jakarta: Rajagrafindo Persada,

${ }^{43}$ Suyono, Analisis Regresi Untuk Penelitian Cet - 1, ( Yogyakarta : Deepublish, 2018 ), 71 - 72.

${ }^{44}$ Suyono, 81- 82.
} 2013), 217. 
dimana rumusan masalah penelitian telah dinyatakan dalam bentuk kalimat pertanyaan.

Dikatakan sementara karena jawaban yang diberikan baru didasarkan pada teori yang relevan, belum didasarkan pada fakta-fakta empiris yang diperoleh melalui pengumpulan data. Jadi hipotesis juga dapat dinyatakan sebagai jawaban teoritis terhadap rumusan masalah penelitian, belum jawaban yang empirik. ${ }^{45}$

Penelitian yang merumuskan hipotesis adalah penelitian yang menggunakan pendekatan kuantitatif, Maka perlu adanya sampel untuk menentukan hipotesis jika tidak ada sampel maka tidak ada hipotesis.

\section{HASIL DAN PEMBAHASAN}

Penelitian ini dilakukan di Pasar Tradisional Pabuaran Subang yang tempatnya cukup jauh dari kota berada di tengah perkampungan berdasarkan penemuan penelitian diambil sampel 36 pedagang dengan hasil selama dilapangan ditemukan beberapa karakteristik berdasarkan data respondon yang dijumpai adapun karakteristik tersebut adalah karakteristik berdasarkan jenis kelamin, karakteristik berdasarkan usia, dan keuntungan pendapatan penjualan perhari.

Dengan berdasarkan jumlah kuesioner 16 pertanyaan sudah dinyatakan valid dan reliabel. Denga hasil statistik terdapat hasil penelitian dengan uji spss 22 for windows didapatkan hasil uji validitas terdapat nilai yang terkecil dari variabel bebas $(\mathrm{X})$ bernilai 0,443 terdapat dari item nomor 7 , sedangkan nilai dari variabel terikat $(Y)$ sebesar 0,459 dari item nomor 6. Sedangkan hasil uji reliabilitas dengan hasil jumlah keseluruhan variabel (X) dengan reliabilitas cronbach's alpha $=$ 0,825 , sedangkan hasil keseluruhan variabel $(\mathrm{Y})$ dengan reliabilitas cronbach's alpha =0,617.

Dengan berdasarkan hasil penelitian para pedagang sudah berperilaku dengan baik dan benar. Pedagang melakukan etika berdagang dengan sistem secara islam dan hampir semua melakukan perilaku berdagang dengan sesuai etika bisnis islam sehingga dapat mempengaruhi tingkat keuntungan penjualan pada tiap - tiap pedagang sebesar 48,9\% koefisien diterminasi ( $\mathrm{R}_{\text {square }}$ ). Sedangkan uji $\mathrm{F}$ dengan nilai 7,597 ingkat signifikan 0,009, uji $\mathrm{t}$ nilai $\mathrm{t}$ hitung sebesar 2,756 > t tabel 2,032 dapat disimpulkan bahwa variabel

${ }^{45}$ Sugiyono, Metode Penelitian Kuantitatif, Kualitatif Dan $R \& D$ (Bandung:Cv Alfabeta,2013), 64. perilaku (X) berpengaruh terhadap variabel keuntungan $(\mathrm{Y})$.

\section{PENUTUP \\ KESIMPULAN}

Kesimpulan yang dapat diambil dari hasil penelitian pengaruh perilaku berdagang terhadap keuntungan penjualan pada pedagang sembako dapat diartikan sebagai berikut :

1. Perilaku berdagang secara uji $\mathrm{t}$ atau parsial berpengaruh positif signifikan terhadap tingkat keuntungan penjualan.

2. Dan secara uji $F$ atau simultan perilaku berdagang secara islam berpengaruh secara simultan terhadap keuntungan.

Dengan ketentuan hasil penelitiannya berdasarkan koefisien determinan (r sequar) 0,489 yang mengandung pengertian bahwa pengaruh variabel bebas terhadap variabel terikat adalah $48,9 \%$ sedangkan $51,1 \%$ ditentukan oleh faktor lain.

Diketahui nilai $\mathrm{f}$ hitung $=7,597$ dengan tingkat signifikan sebesar $0,009<0,05$ maka model regresi dapat dipakai untuk memprediksi variabel parilaku terhadap keuntungan atau dengan kata lain ada pengaruh variabel $\mathrm{x}$ terhadap variabel y.Sedangkan berdasarkan uji nilai $t$ adalah diketahui nilai $\mathrm{t}$ hitung sebesar 2,756 > $\mathrm{t}$ tabel 2,032 dapat disimpulkan bahwa variabel perilaku (X) berpengaruh terhadap variabel keuntungan $(\mathrm{Y})$.

Dengan hasil tersebut dapat diketahui adanya pengaruh terhadap keuntungan dengan meliputi faktor-faktor perilaku yang mempengaruhi keuntungan tersebut, dengan adanya perilaku yang menggunakan etika bisnis islam dari keseluruhan secara umum pedagang di pasar pabuaran sudah menerapkan etika berdagang secara islam.

Karena sebenarnya mereka sudah melakukan kegiatan usaha itu dengan secara islam namun secara garis besar kata etika bisnis islam itu sebagian belum mengetahui padahal sudah melakukan secara islam dikarenakan faktor pengetahuan dan pendidikan sehingga untuk sebagian kalangan masih serasa asing dengan kata konsep etika bisnis islam.

\section{SARAN}

Berdasarkan dari hasil penelitian yang telah dilakukan ada beberapa saran yang bisa disampaikan dan dipertimbangkan :

1. Pedagang harus selalu menerapkan perilaku baik dan jujur terhadap pembelinya dan lebih 
EKSISBANK Vol. 3 No. 1 Juni 2019

memahami lagi berdagang dengan etika bisnis islam namun yang dilakukan sudah dengan cara islami.

2. Harus tetap berbuat adil terhadap pembeli kepada setiap pelanggannya dalam usaha pedagang harus menerapkan secara penuh tanggung jawab agar saling menguntungkan dan tidak merugikan salah satu pihak.

3. Tetap berlaku ramah tamah agar pembeli tetap nyaman walau perolehan keuntungan sedikit perilaku baik tetap harus diterapkan dalam berdagang dengan etika bisnis Islam bekerja karena ridanya allah dan memperoleh hasil keuntungan karna ridanya allah juga.

\section{DAFTAR PUSTAKA}

Isnaini Harahap Dkk, 2015. Hadis-Hadis Ekonomi, Jakarta: Kencana Prenadamedia Group.

H. Abdul Ghofur, 2017. Pengantar Ekonomi Syariah Konsep Dasar,Paradigma, Pengembangan Ekonomi Syariah, Depok : PT Rajagrafindo Persada.

Mukhtar Samad, 2016. Etika Bisnis Syariah Berbisnis Sesuai Dengan Moral Islam, Yogyakarta : Sunrice Book.

Herri Zan Pieter Dkk, 2011. Pengantar Psikopatologi Untuk Keperawatan, Jakarta:Kencana Prenadamedia Group.

Buku Frofil Pasar Pabuaran Subang, Dinas Perindustrian Perdagangan Dan Pengelolaan Pasar Kabupaten Subang.

Dini Hertita, 2018. Setiap Pembisnis Harus Punya Buku Ini Rahasia Meningkatkan Income Dengan Pelayanan, Jakarta : PT Elex Media Komputindo.

Hj. Apiaty Kamaluddin, 2017. Administrasi Bisnis, Makasar: CV Sah Media.

Arif Yusuf Hamali, 2016. Pemahaman Strategi Bisnis \& Kewirausahaan, Jakarta : Kencana Prenadamedia Group.

Yaksan Hamzah Dkk, 2014. Etika Bisnis Islam, Makasar :Kretakupa.

H. Idris, 2015. Hadis Ekonomi Ekonomi Dalam Perpektif Hadis Nabi Cetakan Ke - $3 \mathrm{Mei}$ 2017, Jakarta : Kencana Prenadamedia Group.

Sattar, 2017. Pengantar Bisnis, (Yogyakarta : Deepublish Grup Penerbitan Cv Budi Utama.

Muhammad Anwar, 2014. Pengantar Kewirausahaan Teori Dan Aplikasi, Jakarta : Kencana Prenadamedia Group.

Moch Nazir, 2014. Metode Penelitian (Bogor:Ghalia Indonesia.
Asep Saepul Hamdi Dkk, 2014. Metode Penelitian Kuantitatif Aplikasi Dalam Pendidikan, Yogyakarta : Deepublish.

Muhammad , 2013. Metodelogi Penelitian Ekonomi Islam Pendekatan Kuantitatif, Jakarta: Pt Rajagrafindo Persada.

Sugiyono, 2012. Metode Penelitin Bisnis, Jakarta : Alfabeta.

Suryani dan Hendryadi, 2015. Metode Riset Kuantitatif Teori dan Aplikasi pada Penelitian Bidang Manajemen dan Ekonomi Islam, Jakarta: Prenadamedia Group.

H. Fajri Ismail, 2018. Statistika Untuk Penelitian Pendidikan Dan Ilmu - Ilmu Sosial Edisi Pertama, Jakarta : Kencana Prenada Media Group.

Sugiyono, 2017. Statistika Untuk Penelitian, Bandung: Alfabeta, 2017.

Eko Nugroho, 2018. Prinsip - Prinsip Menyusun Kuesoner, Malang: UB Press.

Fandi Rosi Sarwo Edi, 2016. Teori Wawancara Psikodignostik, Yogyakarta : Leutikaprio.

Ansofino Dkk, 2016. Buku Ajar Ekonometrika, Yogyakarta : Deepublish.

Jonatan Sarwono \& Herlina Budiono, 2012. Statistik Terapan Aplikasi Untuk Riset Skripsi, Tesis Dan Disertasi, (Menggunakan Spss,Amos Dan Excel),(Jakarta : PT Elex Media Komputindo.

Suyono, 2018. Analisis Regresi Untuk Penelitian Cet-1, Yogyakarta : Deepublish.

Sugiyono, 2013. Metode Penelitian Kuantitatif, Kualitatif Dan $R \& D$ (Bandung:Cv Alfabeta. 